\title{
Protulactones A and B: Two New Polyketides from the Marine-derived Fungus Aspergillus sp. SF-5044
}

\author{
Jae Hak Sohn and Hyuncheol Oh* \\ College of Medical and Life Sciences, Silla University, Busan 617-736, Korea. *E-mail: hoh@silla.ac.kr \\ Received March 2, 2010, Accepted April 20, 2010
}

\begin{abstract}
Protulactones A (1) and B (2), two new polyketide-derived fungal metabolites, have been isolated from an EtOAc extract of the marine-derived fungus Aspergillus sp. SF-5044 by various chromatographic methods. The structures of $\mathbf{1}$ and $\mathbf{2}$ were mainly determined by analysis of the NMR spectroscopic data and MS data, along with chemical methods such as Mosher method. Protulactones A (1) and B (2) are new members of polyketide-derived secondary metabolites, possessing unique ring systems among the fungal metabolites produced by the genus Aspergillus.
\end{abstract}

Key Words: Protulactone, Marine-derived fungus, Fungal metabolites, Polyketide, Aspergillus

\section{Introduction}

Marine microorganisms have been recognized as important sources for structurally diverse bioactive secondary metabolites. ${ }^{1,2}$ The marine ecosystem is comprised of fungi that grow and sporulate in a marine environment (obligate marine fungi), and that are from terrestrial or freshwater environment, but still grow in the marine environment (facultative marine fungi). ${ }^{3}$ The marine fungi are suggested to have evolved unique metabolic pathways that are responsive to salt concentration, and thus have shown great potential as suggested by the diversity of secondary metabolites as well as their various biological activities. ${ }^{3,4}$ As part of our on-going studies on secondary metabolites from marine microorganisms from Korea, ${ }^{5-8}$ we have investigated the chemical constituents of the organic extract obtained from cultures of the marine-derived fungus Aspergillus sp. SF5044. This paper describes the isolation and structure elucidation of two new secondary metabolites, named protulactones A (1) and B (2).

\section{Experimental}

General experimental procedures. Optical rotation was recorded on a Perkin Elmer 341 digital polarimeter. NMR spectra (1D and 2D) were recorded in acetone- $d_{6}, \mathrm{CDCl}_{3}$, and $\mathrm{CD}_{3} \mathrm{OD}$ using a JEOL JNM ECP-400 spectrometer (400 MHz for ${ }^{1} \mathrm{H}$ and $100 \mathrm{MHz}$ for ${ }^{13} \mathrm{C}$ ). Chemical shifts were referenced relative to tetramethylsilane $\left(\delta_{\mathrm{H}} / \delta_{\mathrm{C}}=0\right)$. Heteronuclear Multiple Quantum Coherence (HMQC) and Heteronuclear Multiple Bond Coherence $(\mathrm{HMBC})$ experiments were optimized for ${ }^{1} J_{\mathrm{CH}}=140 \mathrm{~Hz}$ and ${ }^{\mathrm{n}} J_{\mathrm{CH}}=8 \mathrm{~Hz}$, respectively. ESIMS data were obtained using a Q-tof micro LC-MS/MS instrument (Waters, USA) Korea University, Seoul, Korea. Solvents for extractions and flash column chromatography were reagent grade and used without further purification. Solvents used for HPLC were analytical grade. Flash column chromatography was carried out using Merck LiChroprep RP-18 (40 - $63 \mu \mathrm{m})$. HPLC separations were performed on a Shiseido Capcell Pak $\mathrm{C}_{18}$ column $(10 \times 250 \mathrm{~mm}$; 5 - $\mu \mathrm{m}$ particle size) with a flow rate of $2 \mathrm{~mL} / \mathrm{min}$. Compounds were detected by UV absorption at $210 \mathrm{~nm}$.
Biological material. Aspergillus sp. SF-5044 (deposited at College of Medical and Life Sciences fungal strain repository, Silla University) was isolated from an inter-tidal sediment sample collected from the Dadaepo Beach, Busan, Korea in April, 2006. The sediment sample was stored in a sterile plastic bag and transported to the laboratory where it was kept frozen until processed. The sample was diluted 10 -fold using sterile seawater. $1 \mathrm{~mL}$ of the diluted sample was processed utilizing the spread plate method in PDA medium (containing 3\% $\mathrm{NaCl}$ ) plates. The plate was incubated at $25{ }^{\circ} \mathrm{C}$ for 14 days. After purifying the isolates several times, the final pure cultures were selected and preserved at $-70{ }^{\circ} \mathrm{C}$. This fungus was identified based on the analysis of the ribosomal RNA (rRNA) sequences. A GenBank search with the 28S rRNA gene of SF-5044 (Genbank accession number FJ935999) indicated Aspergillus protuberus (FJ176897) and Aspergillus asperescens (EF652495) as the closest matches, showing sequence identities of $99.64 \%$ and $98.22 \%$, respectively. Therefore, the marine-derived fungal strain SF-5044 was identified as Aspergillus sp.

Fermentation, extraction, and isolation. The fungal strain was cultured on 110 petri-dish plates $(90 \mathrm{~mm})$, each containing $20 \mathrm{~mL}$ of potato dextrose agar media with $3 \% \mathrm{NaCl}$. Plates were individually inoculated with $2 \mathrm{~mL}$ seed cultures of the fungal strain. Plate cultures were incubated at $25^{\circ} \mathrm{C}$ for a period of 10 days. Extraction of the agar media with EtOAc $(2 \mathrm{~L})$ provided an organic phase, which was then concentrated in vacuo to yield $2.0 \mathrm{~g}$ of an extract. The EtOAc extract was subjected to $\mathrm{C}_{18}$ flash column chromatography $(5 \times 26 \mathrm{~cm})$, eluting with a stepwise gradient of $20 \%, 40 \%, 60 \%, 80 \%$, and $100 \%$ (v/v) $\mathrm{MeOH}$ in $\mathrm{H}_{2} \mathrm{O}(500 \mathrm{~mL}$ each). The fractions eluted at $40 \% \mathrm{MeOH}(452.7 \mathrm{mg})$ was re-applied to $\mathrm{C}_{18}$ flash column chromatography $(5 \times 22 \mathrm{~cm})$, eluting with a stepwise gradient of $10 \%$ to $100 \%$ (v/v) $\mathrm{MeOH}$ in $\mathrm{H}_{2} \mathrm{O}$ (500 mL each, $10 \%$ increment for each fraction). The fraction eluted with $30 \% \mathrm{MeOH}(112.8 \mathrm{mg})$ was further purified by semi-preparative reversed-phase HPLC eluting with a gradient from 7 to $30 \% \mathrm{MeOH}$ in $\mathrm{H}_{2} \mathrm{O}$ ( $0.1 \%$ formic acid) over $90 \mathrm{~min}$ to yield $1\left(3.7 \mathrm{mg}, t_{\mathrm{R}}=77 \mathrm{~min}\right)$ and $2\left(8.7 \mathrm{mg}, t_{\mathrm{R}}=68 \mathrm{~min}\right)$

Protulactone A (1): white oil; $[\alpha]_{\mathrm{D}}^{25}+6(c 0.34, \mathrm{MeOH})$; UV $(\mathrm{MeOH}) \lambda_{\max }(\log \varepsilon) 210(3.30) ;{ }^{1} \mathrm{H},{ }^{13} \mathrm{C} \mathrm{NMR}$, and $\mathrm{HMBC}$ data Table 1; HRESIMS m/z $231.0870(\mathrm{M}+\mathrm{H})^{+}$(calcd. for $\mathrm{C}_{10} \mathrm{H}_{15} \mathrm{O}_{6}$, 
Table 1. 1D and 2D NMR data for 1 in $\mathrm{CD}_{3} \mathrm{OD}$

\begin{tabular}{|c|c|c|c|c|}
\hline no & $\delta_{\mathrm{C}}(\text { mult })^{a}$ & $\delta_{\mathrm{H}}(\text { int, mult, } J \text { in } \mathrm{Hz})^{b}$ & COSY & $\mathrm{HMBC}(\mathrm{H} \rightarrow \mathrm{C})$ \\
\hline 1 & $176.6(\mathrm{~s})$ & - & -- & - \\
\hline 2 & $35.7(\mathrm{t})$ & $\begin{array}{c}2.84(1 \mathrm{H}, \mathrm{dd}, 18.3,4.8) \\
2.52(1 \mathrm{H}, \text { br d, } 18.3)\end{array}$ & $\mathrm{H}-3$ & $\mathrm{C}-1, \mathrm{C}-3, \mathrm{C}-4$ \\
\hline 3 & 77.8 (d) & $4.76(1 \mathrm{H}, \mathrm{m})$ & $\mathrm{H}-2$ & $\mathrm{C}^{-1}, \mathrm{C}^{-}-4$ \\
\hline 4 & 90.9 (d) & $4.77(1 \mathrm{H}, \mathrm{m})$ & H-5 & $\mathrm{C}-1, \mathrm{C}-3, \mathrm{C}-5, \mathrm{C}-6$ \\
\hline 5 & 75.3 (d) & $4.32(1 \mathrm{H}, \mathrm{br} \mathrm{d}, 4.8)$ & $\mathrm{H}-4, \mathrm{H}^{-} 6$ & $\mathrm{C}-3, \mathrm{C}-4, \mathrm{C}-7$ \\
\hline 6 & 88.8 (d) & $3.79(1 \mathrm{H}, \mathrm{dd}, 4.8,4.0)$ & $\mathrm{H}^{-} 5, \mathrm{H}^{-}-7$ & $\mathrm{C}-5, \mathrm{C}-8$ \\
\hline 7 & 69.3 (d) & $5.07(1 \mathrm{H}, \mathrm{dq}, 4.0,6.6)$ & $\mathrm{H}-6, \mathrm{H}-8$ & $C^{-}-5, C^{-}-6, C^{-} 8, C^{-1}$ ' \\
\hline 8 & 14.9 (q) & $1.24(3 \mathrm{H}, \mathrm{d}, 6.6)$ & $\mathrm{H}-7$ & $\mathrm{C}-6, \mathrm{C}-7$ \\
\hline 1 ' & $171.0(\mathrm{~s})$ & - & -- & - \\
\hline $2^{\prime}$ & 19.7 (q) & $1.99(3 \mathrm{H}, \mathrm{s})$ & -- & $\mathrm{C}^{-} \mathbf{1}^{\prime}$ \\
\hline
\end{tabular}

${ }^{a}$ Recorded at $100 \mathrm{MHz}$. Carbon multiplicities were determined by DEPT experiments. ${ }^{b}$ Recorded at $400 \mathrm{MHz}$.

Table 2. $1 \mathrm{D}$ and $2 \mathrm{D}$ NMR data for $\mathbf{2}$ in $\mathrm{CDCl}_{3}$ with drops of $\mathrm{CD}_{3} \mathrm{OD}$

\begin{tabular}{|c|c|c|c|c|}
\hline no & $\delta_{\mathrm{C}}(\mathrm{mult})^{a}$ & $\delta_{\mathrm{H}}(\text { int, mult, } J \text { in } \mathrm{Hz})^{b}$ & COSY & $\operatorname{HMBC}(\mathrm{H} \rightarrow \mathrm{C})$ \\
\hline 1 & $168.6(\mathrm{~s})$ & - & -- & -- \\
\hline 2 & $35.3(\mathrm{t})$ & $\begin{array}{c}2.92(1 \mathrm{H}, \mathrm{dd}, 18.6,1.1) \\
2.85(1 \mathrm{H}, 18.6,4.7)\end{array}$ & $\mathrm{H}-3$ & $C^{-1}, C^{-3}, C^{-4}$ \\
\hline 3 & $69.5(d)$ & $4.12(1 \mathrm{H}, \mathrm{m})$ & $\mathrm{H}-2, \mathrm{H}-5$ & $\mathrm{C}^{-1}, \mathrm{C}-7$ \\
\hline 4 & $65.4(d)$ & $4.09(1 \mathrm{H}, \mathrm{m})$ & H-3, H-5 & $C-3, C-5, C-6$ \\
\hline 5 & $75.0(\mathrm{~d})$ & $4.70(1 \mathrm{H}, \mathrm{ddd}, 4.6,2.3,2.3)$ & $\mathrm{H}^{-} 3, \mathrm{H}^{-} 4, \mathrm{H}-6$ & $\mathrm{C}-1, \mathrm{C}-3, \mathrm{C}-4$ \\
\hline 6 & $71.1(\mathrm{~d})$ & $4.97(1 \mathrm{H}, \mathrm{dd}, 10.1,2.3)$ & H-5, H-7 & $\mathrm{C}-5, \mathrm{C}-7, \mathrm{C}-8, \mathrm{C}-1$ ' \\
\hline 7 & $64.5(d)$ & $3.78(1 \mathrm{H}, \mathrm{dq}, 6.0,10.1)$ & $\mathrm{H}^{-} 6, \mathrm{H}^{-} 8$ & $C-5, C-6, C-8$ \\
\hline 8 & $17.8(q)$ & $1.22(3 \mathrm{H}, \mathrm{d}, 6.0)$ & H-7 & $C^{-}-6, C^{-7}$ \\
\hline 1 ' & $170.7(\mathrm{~s})$ & - & -- & - \\
\hline $2^{\prime}$ & $21.0(q)$ & $2.07(3 \mathrm{H}, \mathrm{s})$ & -- & $\mathrm{C}-1$ \\
\hline
\end{tabular}

${ }^{a}$ Recorded at $100 \mathrm{MHz}$. Carbon multiplicities were determined by DEPT experiments. ${ }^{b}$ Recorded at $400 \mathrm{MHz}$.

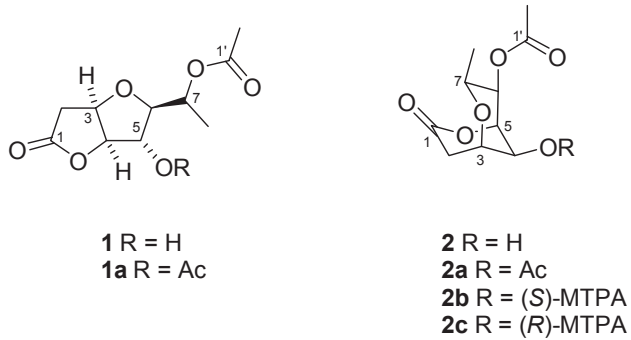

Figure 1. Chemical structures of protulactones A (1) and B (2). The absolute configuration of $\mathbf{1}$ was not assigned.

\subsection{9).}

Protulactone B (2): white oil; $[\alpha]_{\mathrm{D}}^{25}-82(c 0.57, \mathrm{MeOH}) ; \mathrm{UV}$ $(\mathrm{MeOH}) \lambda_{\max }(\log \varepsilon) 210(3.16) ;{ }^{1} \mathrm{H},{ }^{13} \mathrm{C} \mathrm{NMR}$, and HMBC data Table 2; HRESIMS $m / z 231.0869(\mathrm{M}+\mathrm{H})^{+}$(calcd. for $\mathrm{C}_{10} \mathrm{H}_{15} \mathrm{O}_{6}$, 231.0869).

Acetylation of protulactone A (1) and protulactone B (2). Approximately $0.7 \mathrm{mg}$ of protulactone A (1) was mixed with $500 \mu \mathrm{L}$ of acetic anhydride and a few drops of pyridine. The mixture was stirred at room temperature for $24 \mathrm{~h}$, and the reaction was quenched by adding $1 \mathrm{~mL}$ of distilled $\mathrm{H}_{2} \mathrm{O}$. The mixture was partitioned with $\mathrm{CH}_{2} \mathrm{Cl}_{2}(3 \times 1 \mathrm{~mL})$, and the organic phase was evaporated to afford $0.6 \mathrm{mg}$ of the acetyl derivative (1a) of pro- tulactone A: ${ }^{1} \mathrm{H}$ NMR (Acetone- $\left.d_{6}, 400 \mathrm{MHz}\right) \delta$ (integration, multiplicity, $J$ in $\mathrm{Hz}$, assignment): $\delta 2.52(1 \mathrm{H}$, br d, $J=18.1$, H-2), 2.89 (1H, dd, $J=18.1,5.0, \mathrm{H}-2), 4.88(1 \mathrm{H}$, br dd, $J=5.0$, $4.0 \mathrm{~Hz}, \mathrm{H}-3), 4.95$ (1H, br d, $J=4.0, \mathrm{H}-4), 5.29(1 \mathrm{H}$, br d, $J=$ 4.6, H-5), 4.00 (1H, dd, $J=4.6,4.6, \mathrm{H}-6), 5.05$ (1H, dq, $J=4.6$, 6.4, H-7), 1.20 (3H, d, $\left.J=6.4, \mathrm{H}_{3}-8\right), 1.96\left(3 \mathrm{H}, \mathrm{s}, \mathrm{H}_{3}-2\right.$ '), 2.09 $(3 \mathrm{H}, \mathrm{s}, \mathrm{Ac}-5)$; COSY data (Acetone- $\left.d_{6}, 400 \mathrm{MHz}\right) \mathrm{H}-2 \leftrightarrow \mathrm{H}-3$, H-3 ↔ H-4, H-4 ↔ H-5, H-5 ↔ H-6, H-6 ↔ H-7, H-7 ↔ H-8; HRESIMS $m / z 273.0971(\mathrm{M}+\mathrm{H})^{+}$(calc. for $\mathrm{C}_{12} \mathrm{H}_{17} \mathrm{O}_{7}, 273.0974$ ).

In a similar fashion, compound $2(1.0 \mathrm{mg})$, acetic anhydride $(500 \mu \mathrm{L})$, and pyridine (a few drops) were mixed together, allowed to react at room temperature for $24 \mathrm{~h}$, and processed as described above for $\mathbf{1 a}$ to afford $\mathbf{2 a}(0.8 \mathrm{mg}):{ }^{1} \mathrm{H} \mathrm{NMR}\left(\mathrm{CDCl}_{3}\right.$, $400 \mathrm{MHz}) \delta$ (integration, multiplicity, $J$ in $\mathrm{Hz}$, assignment): $\delta$ $2.97\left(2 \mathrm{H}\right.$, br d, $\left.J=2.6, \mathrm{H}_{2}-2\right), 4.28$ (1H, br s, H-3), 5.14 (1H, dd, $J=4.4,1.5, \mathrm{H}-4), 4.77$ (1H, ddd, 4.4, 2.4, 2.4, H-5), 4.89 (1H, dd, $J=9.9,2.4, \mathrm{H}-6), 3.84$ (1H, dq, $J=9.9,5.9, \mathrm{H}-7), 1.26$ $\left(3 \mathrm{H}, \mathrm{d}, J=5.9, \mathrm{H}_{3}-8\right), 2.11$ (3H, s, H3-2'), 2.18 (3H, s, Ac-4); COSY data $\left(\mathrm{CDCl}_{3}, 400 \mathrm{MHz}\right) \mathrm{H}-2 \leftrightarrow \mathrm{H}-3, \mathrm{H}-3 \leftrightarrow \mathrm{H}-4, \mathrm{H}-3 \leftrightarrow$ H-5, H-4 ↔ H-5, H-5 ↔ H-6, H-6 ↔ H-7, H-7 ↔ H-8; HRESIMS $m / z 273.0962(\mathrm{M}+\mathrm{H})^{+}$(calc. for $\mathrm{C}_{12} \mathrm{H}_{17} \mathrm{O}_{7}, 273.0974$ ).

Preparation of mosher esters of protulactone $\mathrm{B}$ (2). A sample of 2 (0.5 mg, $0.002 \mathrm{mmol}),(R)-\mathrm{MTPACl}$ (7.5 mg, $0.029 \mathrm{mmol})$, and pyridine- $d_{5}(500 \mu \mathrm{L})$ were allowed to react in an NMR tube 
at ambient temperature for $24 \mathrm{~h}$. The ${ }^{1} \mathrm{H}$ NMR data of the (S)-MTPA ester derivative (2b) were obtained directly on the reaction mixture by analysis of the ${ }^{1} \mathrm{H}$ NMR and COSY spectra: ${ }^{1} \mathrm{H}$ NMR (pyridine- $\left.d_{5}, 400 \mathrm{MHz}\right) \delta$ (integration, multiplicity, $J$ in $\mathrm{Hz}$, assignment): $\delta 3.29(1 \mathrm{H}, \mathrm{m}, \mathrm{H}-2), 3.34(1 \mathrm{H}, \mathrm{m}, \mathrm{H}-2)$, $4.66(1 \mathrm{H}, \mathrm{m}, \mathrm{H}-3), 6.17(1 \mathrm{H}, \mathrm{dd}, J=4.8,1.5, \mathrm{H}-4), 5.41(1 \mathrm{H}, \mathrm{m}$, H-5), 5.16 (1H, dd, $J=7.7,2.6, \mathrm{H}-6), 4.13(1 \mathrm{H}, \mathrm{m}, \mathrm{H}-7), 1.20$ $\left(3 \mathrm{H}, \mathrm{d}, J=6.2, \mathrm{H}_{3}-8\right)$.

Similarly, the reaction mixture from another sample of 2 (0.5 mg, $0.002 \mathrm{mmol}),(S)$-MPTACl (7.5 mg, $0.029 \mathrm{mmol}$ ), and pyridine- $d_{5}(500 \mu \mathrm{L})$ was processed as described above for $\mathbf{2} \mathbf{b}$ to afford $(R)$-MTPA ester derivative $2 \mathrm{c}:{ }^{1} \mathrm{H}$ NMR (pyridine- $d_{5}$, $400 \mathrm{MHz}) \delta$ (integration, multiplicity, $J$ in $\mathrm{Hz}$, assignment): $\delta$ 3.33 (1H, m, H-2), 3.37 (1H, m, H-2), 4.77 (1H, m, H-3), 6.16 $(1 \mathrm{H}, \mathrm{dd}, J=5.1,2.2, \mathrm{H}-4), 5.34(1 \mathrm{H}, \mathrm{m}, \mathrm{H}-5), 5.10(1 \mathrm{H}, \mathrm{dd}, J=$ 9.9, 2.6, H-6), 4.13 (1H, m, H-7), 1.23 (3H, d, $\left.J=6.2, \mathrm{H}_{3}-8\right)$.

\section{Results and Discussion}

Protulactone $\mathrm{A}$ (1) has the molecular formula $\mathrm{C}_{10} \mathrm{H}_{14} \mathrm{O}_{6}$, as deduced from ${ }^{13} \mathrm{C}$ NMR and HRESIMS data. This formula indicated four degrees of unsaturation. The ${ }^{1} \mathrm{H}$ NMR and DEPT data revealed the presence of two methyl groups, a methylene unit, and five $\mathrm{sp}^{3}$ oxymethine units. Comparison of the DEPT results and molecular formula indicated the presence of one exchangeable proton. These data, together with the signals corresponding to two carboxyl groups ( $\delta 170.5$ and 176.2) observed in the ${ }^{13} \mathrm{C}$ NMR data, indicated that compound 1 must be a bicyclic compound possessing a free hydroxy group to account the molecular formula. The COSY (Table 1) data defined the partial proton spin systems in $\mathbf{1}$ corresponding to C-2 - C-3 and C-4 - C-8. The existence of vicinal coupling between $\mathrm{H}-3$ and $\mathrm{H}-4$ remained ambiguous due to the close proximity of their proton signals. The ${ }^{13} \mathrm{C}$ NMR signal position assignments were confirmed by HMQC data (Table 1), and connectivities among the subunits in 1 were deduced from HMBC correlations (Table 1). For example, correlations of $\mathrm{H}-2$ and $\mathrm{H}-3$ with the carboxyl carbon $\mathrm{C}-1$, along with a correlation of $\mathrm{H}-5$ with $\mathrm{C}-3$ defined the carbon skeleton $\mathrm{C}-1$ to $\mathrm{C}-8$ in the molecule. In addition, the acetyl group (C-1' and $\mathrm{C}-2$ ') was defined by chemical shift consideration and a HMBC correlation of $\mathrm{H}_{3}-2$ ' with $\mathrm{C}-1$ '. This acetyl group was then connected to $\mathrm{C}-7$ on the basis of a HMBC correlation of H-7 with C-1'. Since there were no positive HMBC correlations to define the position of a hydroxyl group, compound $\mathbf{1}$ was treated with acetic anhydride, and the formation of the acetate was inferred by the observation of downfield shift of one of the oxymethine proton signals from $\delta 4.32(\mathrm{H}-5)$ to $\delta 5.29$, along with an additional acetate methyl proton signal $(\delta 2.09)$. Therefore, the hydroxy group was located at C-5. A HMBC correlation of $\mathrm{H}-4$ with $\mathrm{C}-1$ led to the formation of $\gamma$-lactone moiety in the molecule. To fulfill the unsaturation and the molecular formula, C-3 and C-6 should be connected via an ether linkage to form a five-membered ring. Taken together, the gross structure of 1 was determined as shown.

The relative stereochemistry shown for $\mathbf{1}$ was assigned on the basis of the examination of NOESY data and the $J$-values, along with the inspection of the molecular modeling (ChemDraw Ultra 11.0 ) of $1 \mathrm{a}$. The $J$-value $(4.0 \mathrm{~Hz}$ ) for $\mathrm{H}-3 / \mathrm{H}-4$ coupling indicated that these protons should be in the cis configuration. ${ }^{9}$ The observed $J$-value for $\mathrm{H}-4 / \mathrm{H}-5$ coupling was close to $0 \mathrm{~Hz}$, indicating their trans configuration, in which their dihedral angel is close to $90^{\circ}$ in the stable molecular model. The NOE correlation of H-3 with H-6 suggested that they are on the same face of the ring system. Thus, the relative configurations of C-3, C-4, C-5, and $\mathrm{C}-6$ were assigned as shown, and this assignment was well matched with that of goniofufurone, ${ }^{9}$ which possesses similar $\gamma$-lactone moiety with that of $\mathbf{1}$. The absolute configurations of 1 could not be determined in this study.

Protulactone B (2) has the molecular formula $\mathrm{C}_{10} \mathrm{H}_{14} \mathrm{O}_{6}$, as deduced from ${ }^{13} \mathrm{C}$ NMR and HRESIMS data (four degrees of unsaturation). Although protulactone B (2) was suggested to be related to protulacton $\mathrm{A}(\mathbf{1})$ by comparing the ${ }^{1} \mathrm{H}$ and ${ }^{13} \mathrm{C} \mathrm{NMR}$ data, the gross structure of $\mathbf{2}$ was determined to be somewhat different on the basis of detailed analysis of 2D NMR data. As is the case with $\mathbf{1}$, COSY (Table 2) experiments only defined the partial proton spin systems in 2 corresponding to C-2 - C-3 and C-4 - C-8 due to some signal overlapping. To identify the complete spin system and the position of the hydroxy group in the molecule, compound $\mathbf{2}$ was converted to the acetate derivative, leading to the observation of downfield shift of one of the overlapping oxymethine proton signals. COSY data for the acetate derivative clearly defined the proton spin systems corresponding to $\mathrm{C}-2$ - C-8, and placed the hydroxy group at C-4 by analogues interpretation to the case of compound $\mathbf{1}$. Next, connections of the spin system and the remaining moieties in the molecule were deduced from HMBC correlations (Table 2). HMBC correlations of $\mathrm{H}_{2}-2$ and $\mathrm{H}-3$ with $\mathrm{C}-1$ allowed the connection of C-1 and C-2. C-1 was then connected to C-5 via oxygen on the basis of chemical shifts consideration and a HMBC correlation of $\mathrm{H}-5$ with $\mathrm{C}$-1, leading to the formation of six-membered $\delta$-lactone ring moiety. The ether linkage between $\mathrm{C}-3$ and $\mathrm{C}-7$ was evident by the observation of a HMBC correlation of $\mathrm{H}-3$ with $\mathrm{C}-7$. Finally, the acetyl group, defined by $\mathrm{HMBC}$ correlation of $\mathrm{H}_{3}-2$ ' with C-1', was connected to C-6 by a HMBC correlation of H-6 with C-1'. Therefore, the planar structure of compound 2 was assigned as shown.

The relative stereochemistry shown for $\mathbf{2}$ was assigned on the basis of the examination of molecular model of the acetylated derivative of compound $\mathbf{2}$ and its NOESY data. Considering the bicyclic rigidity of the compound, a NOE correlation of H-6 with H-3 suggested that these protons are on the same face of the molecule, thus indicating the axial position of H- 6 in the pyran moiety of the molecule as wells as the equatorial position of $\mathrm{H}-3$ in the six-membered $\delta$-lactone ring. A NOE correlation of $\mathrm{H}-7$ with $\mathrm{H}_{2}-2$ suggested the axial position of $\mathrm{H}-7$ in the pyran ring, and the $J$-value $(9.9 \mathrm{~Hz})$ for $\mathrm{H} 6 / \mathrm{H} 7$ coupling supported this assignment. A NOE correlation between $\mathrm{H}_{2}-2$ and $\mathrm{H}-4$ allowed the assignment of the acetyl group at the equatorial position of the $\delta$-lactone ring moiety, and this assignment was consistent with the $J$-values $\left(J_{\text {Heq-3/Hax-4 }}=1.5 \mathrm{~Hz}, J_{\text {Hax }-4 / \mathrm{Heq}-5}=4.4 \mathrm{~Hz}\right)$.

To establish the absolute configuration at C-4 of protulactone B (2), the $S$ - and $R$-Mosher esters ( $\mathbf{2} \mathbf{b}$ and $\mathbf{2 c}$ ) of the compound was prepared. ${ }^{10}$ Analysis of ${ }^{1} \mathrm{H}$ NMR and COSY spectra obtained by directly measuring the separate reaction NMR tubes ${ }^{11}$ allowed the assignment of the proton chemical shifts for the two diastereomeric esters $\mathbf{2 b}$ and $\mathbf{2 c}$ in proximity of the esterified 


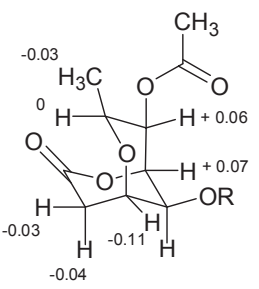

Figure 2. $\Delta \delta$ values $\left[\Delta \delta\right.$ (in ppm) $\left.=\delta_{S}-\delta_{R}\right]$ obtained for the $(S)$ - and $(R)$-MTPA esters of compound $\mathbf{2}$ ( $\mathbf{2 b}$ and $\mathbf{2 c}$, respectively).

carbon (C-4). The differences in chemical shift values $\left(\Delta \delta=\delta_{S}\right.$ $\left.\delta_{R}\right)$ for the two diastereomeric esters $\mathbf{2} \mathbf{b}$ and $\mathbf{2} \mathbf{c}$ were calculated in order to assign the absolute configurations at C-4 (Figure 2). Calculations for all of the relevant signals except $\mathrm{H}_{3}-8$ suggested the $S$ absolute configuration at C-4.

In closing, two new polyketide-derived (tetraketide) fungal metabolites, protulactones $\mathrm{A}$ and $\mathrm{B}$ have been isolated from the marine-derived fungus Aspergillus sp. SF-5044. A number of metabolites containing the furo[3,2-b] furan ring system as found in 1, or the dioxabicyclo[3.3.1] nonane ring system as found in $\mathbf{2}$ have been reported from nature. ${ }^{12}$ Specifically, giniofuurone from the stem bark of Goniothalamus giganteus ${ }^{9}$ and a tetraketide from the leaves of Euscaphis japonica ${ }^{13}$ share very close structural features with those in $\mathbf{1}$ and $\mathbf{2}$, respectively. However, to our knowledge, fungal metabolites possessing these types of ring systems have not been previously reported from any member of the genus Aspergillus.

Acknowledgments. Mass data were obtained at the Lab of
Natural Products and Metabolomics, Division of Biotechnology of Korea University.

Supporting Information. The Supporting Information (1Dand 2D-NMR spectra for compounds $\mathbf{1}, \mathbf{1 a}, \mathbf{2}$, and 2a) is available on request from the correspondence author (E-mail: hoh@, silla.ac.kr).

\section{References}

1. Molinski, T. F.; Dalisay, D. S.; Lievens, S. L.; Saludes, J. P. Nat. Rev. Drug Discov. 2009, 8, 69.

2. Fenical, W.; Jensen, P. R. Nat. Chem. Biol. 2006, 2, 666.

3. Bugni, T. S.; Ireland, C. M. Nat. Prod. Rep. 2004, 21, 143.

4. Konig, G. M.; Kehraus, S.; Seibert, S. F.; Abdel-Lateff, A.; Muller, D. ChemBioChem 2006, 7, 229.

5. Choi, Y.-H.; Sohn, J.-H.; Lee, D.; Kim, J. K.; Kong, I. S.; Ahn, S. C.; Oh, H. Tetrahedron Lett. 2008, 49, 7128.

6. Kim, M.-Y.; Sohn, J. H.; Ahn, J. S.; Oh, H. J. Nat. Prod. 2009, 72, 2065.

7. Seo, C.; Sohn, J. H.; Oh, H.; Kim, B. Y.; Ahn, J. S. Bioorg. Med. Chem. Lett. 2009, 19, 6095.

8. Seo, C.; Oh, H. Bull. Korean Chem. Soc. 2009, 30, 1181.

9. Fang, X.P.; Anderson, J. E.; Chang, C.-J.; Fanwick, P. E.; McLaughlin, J. L. J. Chem. Soc. Perkin Trans. 1 1990, 1655.

10. Seco, J. M.; Quinñoá, E.; Riguera, R. Chem. Rev. 2004, $104,17$.

11. Su, B.-N.; Park, E. J.; Mbwambo, Z. H.; Santarsiero, B. D.; Mesecar, A. D.; Fong, H. H. S.; Pezzuto, J. M.; Kinghorn, A. D. J. Nat. Prod. 2002, 65, 1278.

12. Dictionary of Natural Products on CD-ROM, Chapman \& Hall/ CRC Press: Boca Raton, FL, 2007.

13. Takeda, Y.; Okada, Y.; Masuda, T.; Hirata, E.; Shinzato, T.; Takushi, A.; Yu, Q.; Otsuka, H. Chem. Pharm. Bull. 2000, 48, 752. 